\title{
Influence of Biopreparation "Alirin-B” on Cytomorphometric Characteristics of Conidia of Fungus Fusarium spp. Causing Potato Dry Rot
}

\author{
Zhilinskaya Nadezhda \\ St. Petersburg, Russia \\ St. Petersburg, Russia \\ jilinskie@mail.ru \\ Milovanovich Ekaterina \\ ITMO University \\ St. Petersburg, Russia
}

Graduate School of Biotechnology and Food Science

Peter the Great St. Petersburg Polytechnic University

N.N. Petrov National Medical Research Center of Oncology

\author{
Eliseeva Svetlana \\ Graduate School of Biotechnology and Food Science \\ Peter the Great St. Petersburg Polytechnic University \\ St. Petersburg, Russia \\ sel1847@mail.ru
}

\begin{abstract}
Bazarnova Iulia
Graduate School of Biotechnology and Food Science Peter the Great St. Petersburg Polytechnic University St. Petersburg, Russia

j.bazarnowa2012@yandex.ru
\end{abstract}

\begin{abstract}
Food and agricultural product safety during manufacture and turnover is a keystone in development of food market in many countries. Fusarium dry rot is the most common plant disease. Biological protection of agricultural plants is one of the alternative methods to reduce soil damage against mineral fertilizers. Our work was to study the dynamic influence of biological fungicidal commercial product "Alirin - B" with active substance of Bacillus subtilis B-10 VIZR on digital cytomorphometric characteristics of Fusarium spp. reproduction cells. The fungal mycelium was taken in the $5 \%$ glucose solution. Two sample cultivated types were researched: conidia in glucose solution with fungal mycelium (control), conidia in glucose solution with fungal mycelium and "Alirin - B" (experiment). The individual macro- and microconidia digital cell cytomorphometric characteristics of Fusarium spp. (square, length, width, number) were obtained. "Alirin-B" obliterates macro- and microconidia and thus affects the Fusarium spp. reproduction system. The digital microorganism conidia cytomorphometric method could be recommended as a testing system in development of new plant biofungicidal products.
\end{abstract}

Keywords- potato dry rot, Fusarium spp., conidia digital cytomorphometry, fungicidal biological product Alirin-B

\section{INTRODUCTION}

Safety of food and agricultural products during production and turnover is a keystone in development of food market in many countries [1].

Potato is one of the leading agricultural crops in many countries. A total of 53 million tonnes of potatoes were harvested in the EU in 2015. Germany was the main producer [2]. In 2015, 53 million tonnes of potatoes were harvested in the
EU. Germany was the biggest producer with a share of $19.5 \%$, ahead of France $(13.4 \%)$, the Netherlands $(12.5 \%)$, Poland $(11.6 \%)$, and the United Kingdom (10.5\%).

Despite the fact that the potato is a high yielding culture, a total number of potato tubers has significantly reduced in some unfavourable years. The main reason of the potato harvest decrease is the damage of the potato tubers by bacterial and fungal infections such as Rhizoctonia, phoma rot, late blight, Fusarium and others [3].

Fusarium dry rot is a second most common plant disease after late blight. Fusarium spp. belongs to the division Ascomycota and causes many important diseases. These fungi may contaminate food products with mycotoxins, threatening to animal and human health, can cause a wide spectrum of human infections, especially in immune compromised patients (cancer) or HIV positive patients [4, 5].

The fungal genus of Fusarium spp. is wide spread in many regions all over the world [6, 7]. Fusarium sambucinum, Fusarium coeruleum, Fusarium solani App.et. Wr. Fusarium avenaceum are the main potato pathogens (Fig.1). Safety of food and agricultural products during production and turnover is a keystone in development of food market in many countries [1].

Potato is one of the leading agricultural crops in many countries. A total of 53 million tonnes of potatoes were harvested in the EU in 2015. Germany was the main producer [2]. In 2015, 53 million tonnes of potatoes were harvested in the EU. Germany was the biggest producer with a share of $19.5 \%$, 
ahead of France (13.4\%), the Netherlands (12.5\%), Poland (11.6\%), and the United Kingdom (10.5\%).

Despite the fact that the potato is a high yielding culture, a total number of potato tubers has significantly reduced in some unfavourable years. The main reason of the potato harvest decrease is the damage of the potato tubers by bacterial and fungal infections such as Rhizoctonia, phoma rot, late blight, Fusarium and others [3].

Fusarium dry rot is a second most common plant disease after late blight. Fusarium spp. belongs to the division Ascomycota and causes many important diseases. These fungi may contaminate food products with mycotoxins, threatening to animal and human health, can cause a wide spectrum of human infections, especially in immune compromised patients (cancer) or HIV positive patients $[4,5]$.

The fungal genus of Fusarium spp. is wide spread in many regions all over the world [6, 7]. Fusarium sambucinum, Fusarium coeruleum, Fusarium solani App.et. Wr. Fusarium avenaceum are the main potato pathogens (Fig.1).

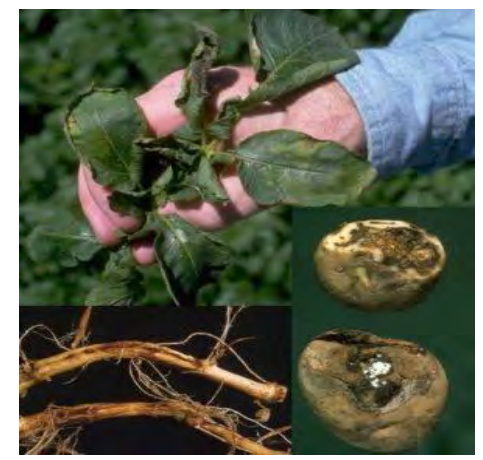

Fig. 1. Tuber contaminated by Fusarium spp. causing potato dry rot.

Fusarium belongs to the imperfect fungi class. Sporulation is the main way of fungal reproduction by macro- or microconidia which are varied in shape, size and structure [8]. A new molecular method of PCR is widely used in science experiments together with traditional morphological and physiological research methods of Fusarium spp. [9, 10]. Zhilinskaya N. [11] was the first to propose bioinformatics based on the thermodynamic laws in microbiological cell research both for yeast and for Fusarium spp. causing potato dry rot [12].

Application of chemical fungicides in agriculture leads to pollution of environment. Biological protection of agricultural plants is one of the alternative methods to reduce soil damage against mineral fertilizers. Biologicals suppress the tissue pathogenic flora by their own microorganisms or plant biologically active extracts [13]. Bazarnova I. and Ivanchenko O. [14] showed that phytoextracts from Thymus vulgaris and Achillea millefolium have antimicrobial properties for E.coli, and extract from Hypericum was effective against Rhizopus stolonifer.

On the other hand, microorganisms which are capable of secreting antibiotics can be an alternative way of reducing the inoculum potential of different phytopathogenes such as Fusarium, Verticillium, Ascochyta, Sclerotinia, Oidium, Bipolaris, Alternaria, Erysiphe, Colletotrichum species and others. More than 1000 strains of microorganisms including actinomycetes and mold fungi have the highest antifungal activity against 15 fungal pathogens. They suppressed completely fungal mycelium growth of Fusarium graminearum, $F$. culmorum, $F$. oxysporum, $F$. sporotrichiella, F. moniliforme, Rhizoctonia solani, Phoma exigua, Verticillium dahliae, Ascochyta melonis, Sclerotinia sclerotiorum, Bipolaris sorokiniana, Alternaria brassicicola, Colletotrichum atramentarium, Botrytis cinerea and others. One of these strains is Bacillus subtilis-10 VIZR. Alirin B is based on the living cultures of Bacillus subtilis-10 VIZR respectively [15]. Vegetation and field tests have shown that Alirin B can be used for decreasing the incidence of cucumber, tomato, vegetable marrow and potato diseases. Application of this bioproduct enables one not only to protect it from pathogens and to increase the yield of agricultural crops, but also to obtain ecologically pure products and to avoid the soil contamination with toxic substances.

The chemical compound of plant tissue is a good growth medium for microorganisms. That is why, the fungi of the genus Fusarium should be considered as one of the components of the biological ecosystem. There are no data on using the digital cytomorphometry in the study of biological fungicide influence on the Fusarium reproductive system - macro- and microconidia growth and proliferation.

Our work was to explore the influence dynamic of biological fungicidal commercial product "Alirin-B" with active substance of Bacillus subtilis B-10 VIZR on digital cytomorphometric characteristics of Fusarium spp. reproduction cells.

\section{MATERIALS AND METHODS}

As the object of study was chosen potatoes (Solanum tuberosum, SEM. Solanaceae) varieties "Nevsky" grown in the Leningrad region. Harvesting - autumn 2017. The study was carried out 6 months after laying the potatoes for storage.

The potato "Nevsky" belongs to an intensive type of varieties and well responds to fertilizer application. Investigated tubers were in storage for 6 months after the harvest in 2017 ; the average storage temperature was $+18^{\circ} \mathrm{C}$, relative humidity was $75 \%$.

Sampling from potato lot was carried out in accordance with ISO 7002:1986. Potatoes tubers with Fusarium contamination signs were selected. The qualitative method was used to detect the presence or absence of Fusarium sp. in potato tissues (ISO 7218-2011). The changes of tuber with dry rot were: drying up, shrivelling and falling off the epithelial tissue. The tuber was cut with a knife along the longitudinal axis through the stolon and the tuber flesh was examined.

Three areas of the damaged potato tuber were studied:

- epicenter of contaminated potato tuber tissue; 
- peripheral area of potato tuber tissue contamination;

- potato tuber tissue outside the epicenter of contamination

The destruction of potato tuber tissue was maximally expressed in the epicenter of contamination. The epicenter of contaminated plant tissue was studied. The flesh looked like a dry rotten black mass with voids, filled with fluffy mycelium of the fungus in the epicenter of contaminated plant tissue.

The fungal mycelium was taken in the $5 \%$ glucose solution. Two sample types were researched: conidia in glucose solution with fungal mycelium (control), conidia in glucose solution with fungal mycelium and "Alirin - B" (experiment). The cell incubation was carried out in the thermostatized system for 2 , 48 and 144 hours at temperature $+30^{\circ} \mathrm{C}$ within $6.0-8.0$ of $\mathrm{pH}$.

The dynamics of "Alirin-B" influence on Fusarium macroconidia and microconidia was studied after 2 hours, 48 hours (2 days), 144 hours (6 days) after adding the biopreparation to the $5 \%$ glucose solution with fungal mycelium. Fixed samples of Fusarium spp. cells were stained by $1 \%$ of methylene blue solution. Morphological study of the fixed microorganism slide preparation was made on microscope "Nicon Eclipse Ni". The species identification of Fusarium according to the morphological characteristics of their macroand microconidia was not studied. Macro- and microconidia digital morphometric characteristics of Fusarium spp. (square, length, width, number) were obtained by the automatic image analyzer "Nicon" with the software program «Image $J$ » under magnification of $x 400$ or $x 1000$. The account was carried out in 20 randomly selected view fields per 100 cells in each. Statistics was studied by GraphPad Prism 6.

\section{RESULTS AND DISCUSSION}

The results of microscopic study of Fusarium spp. mycelium and conidia from the epicenter of contaminated potato tuber tissues are presented in Fig. 2.

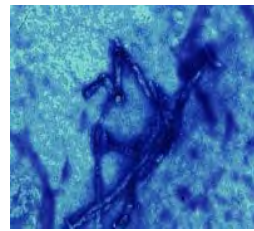

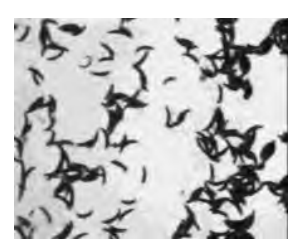

b

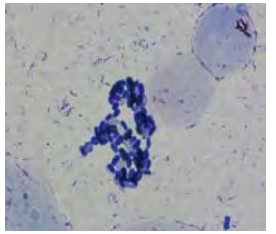

Fig. 2. Mycelium and conidia of the Fusarium spp. from the epicenter of contaminated potato tuber tissues:

a. mycelium of the Fusarium spp. from contaminated potato tuber tissue, septated hyphae with straight simple thin long oval microconidia ( $x$ 400);

b. the epicenter of contaminated potato tuber tissue (x 400);

c. microconidia cluster of the Fusarium spp. from contaminated potato tuber tissue, (x 1000)

Methylene blue.

The macroconidia of Fusarium spp. ranged from fusiform to lanceolate mostly with visible three partitions (Fig.3). Cells in the central part are typically square. The apical cell is slightly elongated, gradually and evenly tapering, and somewhat curved. The microconidia are oval, reniform, elongated oval or sometimes ovoid with a truncate base.

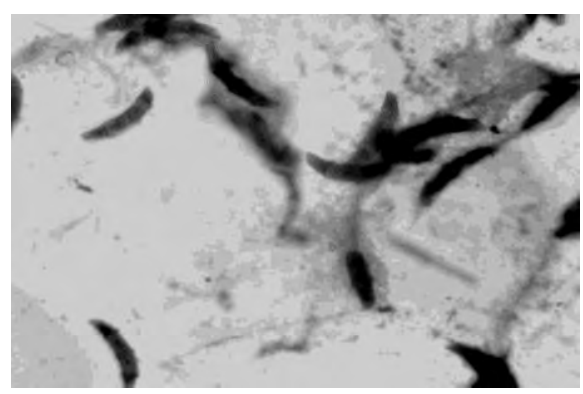

Fig. 3. Macroconidia of Fusarium spp. causing potato dry rot (x 1000). Methylene blue

The results of digital cytomorphometric measurements of the Fusarium macroconidium cells in the control and experimental samples are presented in Table 1.

TABLE I. MORPHOMETRIC CHARACTERISTICS OF FUSARIUM SPP. MACROCONIDIA CAUSING POTATO DRY ROT

\begin{tabular}{|c|c|c|c|c|}
\hline No & $\begin{array}{l}\text { Morphometric } \\
\text { characteristics }\end{array}$ & \multicolumn{3}{|c|}{ Cultivation hours } \\
\hline & Control samples & 2 & 48 & 144 \\
\hline 1 & Area size, $\mu \mathrm{m}^{2}$ & $\begin{array}{c}32.58 \mu \mathrm{m}^{2} \pm \\
4.24\end{array}$ & $\begin{array}{c}49.56 \mu \mathrm{m}^{2} \pm \\
5.23\end{array}$ & $\begin{array}{c}74.35 \mu \mathrm{m}^{2} \\
\pm 10.46\end{array}$ \\
\hline 2 & Cell length, $\mu \mathrm{m}$ & $\begin{array}{c}16.02 \mu \mathrm{m} \pm \\
1.47\end{array}$ & $\begin{array}{c}18.64 \mu \mathrm{m} \pm \\
1.42\end{array}$ & $\begin{array}{c}21.19 \mu \mathrm{m} \pm \\
1.44 \\
\end{array}$ \\
\hline 3 & Cell width, $\mu \mathrm{m}$ & $\begin{array}{c}1.99 \mu \mathrm{m} \pm \\
0.13\end{array}$ & $\begin{array}{l}2.42 \mu \mathrm{m} \pm \\
0.14\end{array}$ & $\begin{array}{c}3.51 \mu \mathrm{m} \pm \\
0.28\end{array}$ \\
\hline & $\begin{array}{c}\text { Samples with } \\
\text { biological } \\
\text { fungicidal } \\
\text { commercial product } \\
\text { "Alirin - B" } \\
\text { (Russia) }\end{array}$ & & & \\
\hline 1 & Area size, $\mu \mathrm{m}^{2}$ & $\begin{array}{c}35.22 \mu \mathrm{m}^{2} \pm \\
11.30\end{array}$ & $\begin{array}{c}58.23 \mu \mathrm{m}^{2} \pm \\
13.44\end{array}$ & - \\
\hline 2 & Cell length, $\mu \mathrm{m}$ & $\begin{array}{c}16.75 \mu \mathrm{m} \pm \\
2.96\end{array}$ & $\begin{array}{c}21.99 \mu \mathrm{m} \pm \\
4.23\end{array}$ & - \\
\hline 3 & Cell width, $\mu \mathrm{m}$ & $\begin{array}{c}2.29 \mu \mathrm{m} \pm \\
0.28\end{array}$ & $\begin{array}{c}2.84 \mu \mathrm{m} \pm \\
0.17\end{array}$ & - \\
\hline
\end{tabular}

The results obtained show that Fusarium cells have their individual morphometric characteristics. The results of computer morphometric measurements of the Fusarium spp. macroconidia cells in the control samples were following. After 2 hours of cultivation, the area size was $32.58 \mu \mathrm{m}^{2} \pm 4.24$; the cell length $-16.02 \mu \mathrm{m} \pm 1.47$; the cell width $-1.99 \mu \mathrm{m} \pm 0.13$, the amount of sprouted macroconidia was $0 \%$. After 48 hours, the area size was $49.56 \mu \mathrm{m}^{2} \pm 5.23$; the cell length $-18.64 \mu \mathrm{m}$ \pm 1.42 ; the cell width was $2.42 \mu \mathrm{m} \pm 0.14$, the amount of sprouted macroconidia was $40 \%$ in some view fields. After 144 hours, the area size was $74.35 \mu \mathrm{m}^{2} \pm 10.46$; the cell length $21.19 \mu \mathrm{m} \pm 1.44$; the cell width $-3.51 \mu \mathrm{m} \pm 0.28$, the amount of sprouted macroconidia was $43 \%$, mycelium fragments - in some view fields. The microconidia cell area sizes were the following: $3.81 \mu \mathrm{m}^{2} \pm 0.26(2 \mathrm{~h}), 3.89 \mu \mathrm{m}^{2} \pm 0.23(48 \mathrm{~h}), 3.75$ $\mu \mathrm{m}^{2} \pm 0.15$ (144 h). 
The results of computer morphometric measurements of the Fusarium spp. macroconidia cells in the experimental samples were the following. After 2 hours: the area size was $35.22 \mu \mathrm{m}^{2}$ \pm 11.30 ; the cell length $-16.75 \mu \mathrm{m} \pm 2.96$; the cell width -2.29 $\mu \mathrm{m} \pm 0.28$, the amount of sprouted macroconidia was $0 \%$. After 48 hours, the area size was $58.23 \mu \mathrm{m}^{2} \pm 13.44$; the cell length $21.99 \mu \mathrm{m} \pm 4.23$; the cell width $-2.84 \mu \mathrm{m} \pm 0.17$, the amount of sprouted macroconidia was $43 \%$. The microconidia cell area sizes were the following: $3.78 \mu \mathrm{m}^{2} \pm 0.19(2 \mathrm{~h}), 3.52 \mu \mathrm{m}^{2} \pm 0.26$ $(48 \mathrm{~h})$. After 144 hours: macroconidia and microconidia cells were not found in any view fields, mycelium fragments - in some view fields.

Comparative analysis of Fusarium spp. macroconidia cytomprhometric characteristics showed that the values of the control sample cell area size, length and width increased in proportion to the mycelium cultivation time. Maximum size was observed after 144 hours (6 days) of mycelium cultivation in the $5 \%$ glucose solution. The value of the macroconidia cell area size after 144 hours cultivation was 2.28 higher than that after 2 hours of cultivation. These data obtained can be explained by the morphology and nutrition physiology specificity of mycelial mold fungi $[16,17]$.

Comparative analysis of Fusarium spp. macroconidia cytomprhometric characteristics showed that the values of the experimental sample cell area size, length and width increased only up to 48 hours of mycelium cultivation in the $5 \%$ glucose solution. After 144 hour of cultivation, macroconidia and microconidia cells were not found in any view fields. The data obtained show the "Alirin-B" effect on Fusarium reproduction system and confirm its fungicidal properties [15].

The macro- and microconidia number changes under "Alirin-B" are shown in figure 3.

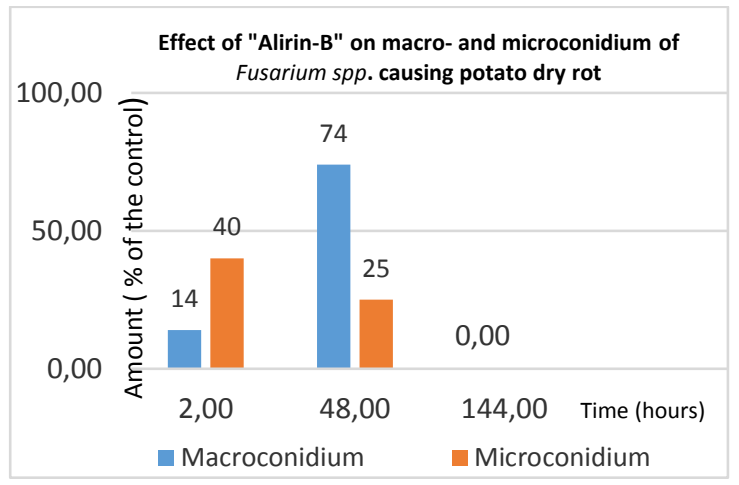

Fig. 4. The dynamic of macro- and microconidia number changes under "Alirin-B".

The quantify results showed that "Alirin-B" especially influence Fusarium microconida: the number decreased from $40 \%(2 \mathrm{~h})$ to $25 \%(48 \mathrm{~h})$ and to $0 \%(144 \mathrm{~h})$. The number of macroconidia increased for the first time from $14 \%(2 \mathrm{~h})$ to 74 $\%(48 \mathrm{~h})$ and then decreased to $0 \%(144 \mathrm{~h})$. This may happen as a result of disruption of the structural and functional integrity of Fusarium cell system and will indicate the biological's efficiency.
It is known that phytopathogenic fungi of the genus Fusarium contaminating potato tubers are parasites. The fungi cells penetrate into the plant tissue and multiply in it by activating their metabolism. It is important to study the Fusarium cell conidia morphometric characteristics in case of development and introduction of the new chemical and biological plant protecting preparations. It should be expected that in the case of the reaction of Fusarium cells on chemical or biological preparations, there will be changes in the number and size of macro- and microconidia. This may be as a result of disruption of the structural and functional integrity of Fusarium cell system and will indicate the efficiency of new biofungicidal products.

\section{CONCLUSIONS}

The individual digital morphometric macro- and microcinidia cell characteristics of Fusarium spp. causing potato dry rot were obtained. "Alirin-B" obliterates macro- and microconidia and thus affects the Fusarium spp. reproduction system.

The method of digital cytomorphometry could be recommended as a testing system in development of new plant biofungicidal products.

\section{References}

[1] A. Rezaei, "Food safety: The farmer first health paradigm", One Health, vol. 5, pp. 69-73, June 2018.

[2] Eurostat Statistics Explained, The EU potato sector - statistics on production, prices and trade, retrieved from: http://ec.europa.eu/eurostat/statistics-explained/index.php/

[3] E. Stefańczyk, S. Sobkowiak, M. Brylińska, J.Śliwka, "Diversity of Fusarium spp. associated with dry rot of potato tubers in Poland", European Journal of Plant Pathology, vol. 145, iss. 4, pp. 871-884, August 2016.

[4] Y. Liu, N. Wang, R. Ye, W. Kao, "Disseminated Fusarium infection in a patient with acute lymphoblastic leukemia: A case report and review of the literature", Oncology Letters, pp. 334-336, December, 6, 2013.

[5] A. Esnakula, I. Summers, and T. Naab, "Fatal disseminated Fusarium infection in a human immunodeficiency virus positive patient", Case Reports in Infectious Diseases, 5 p., April, 23, 2013.

[6] E. Gachango, L. Hanson, A. Rojas, J. Hao, W. Kirk, "Fusarium spp. Causing Dry Rot of Seed Potato Tubers in Michigan and Their Sensitivity to Fungicides", Plant Disease, vol. 96, no. 12, pp. 1767-1774, December 2012.

[7] H.J. Schroers, G.J. Samuels, N. Zhang, D.P. Short, J. Juba, D.M. Geiser, "Epitypification of Fusisporium (Fusarium) solani and its assignment to a common phylogenetic species in the Fusarium solani species complex", Mycologia, vol. 10, pp. 806-819, January, 20, 2017.

[8] J.W. Yang, S.S. Nam, H.U. Lee, K.H. Choi, S.G. Hwang, N.C. Paul, "Fusarium root rot caused by Fusarium solani on sweet potato (Ipomoea batatas) in South Korea", Canadian Journal of Plant Pathology, vol. 40, iss. 1, pp. 90-95, 2018.

[9] P. Heltoft, M.B. Brurberg, M. Skogen, V.H. Le, J. Razzaghian, A. Hermansen, "Fusarium spp. causing Dry Rot on potatoes in Norway and development of a Real-Time PCR method for detection of Fusarium coeruleum", Potato Research, vol. 59, iss. 1, pp. 67-81, 2016.

[10] M. Du, X. Ren, Q. Sun, Y. Wang, and R. Zhang, "Characterization of Fusarium spp. causing potato Dry Rot in China and susceptibility evaluation of Chinese Potato germplasm to the pathogen", Potato Research, vol.55, pp. $175-184,2012$. 
[11] N.T. Zhilinskaia, J.G. Bazarnova, and N.A. Politaeva, "The using of bioinformatics in microbiological research", IX International Congress Biotechnology: state of the art and perspectives, 20-22, February, 2017, vol.2, pp. 300-302, Gostiny Dvor, Moscow [Conference proceedings, 2017]

[12] N. Zhilinskaia, J. Bazarnova, A. Shleikin, L. Peshuk, and O.Galenko, "Using of bioinformatics and computer morphometry in study of Fusarium spp. causing potato dry rot”, Ukrainian Food Journal, vol. 5, iss. 3, pp. 515-522, 2016.

[13] S. M. Farag, K.M. Elhalag, M.H. Hagag, A.S. Khairy, H. M. Ibrahim, M.T. Saker, and N.A. Messiha, "Potato bacterial wilt suppression and plant health improvement after application of different antioxidants", Journal of Phytophatology, vol. 165, iss. 7-8, pp. 522-537, June, 19, 2017.
[14] Y.G. Bazarnova, and O.B. Ivanchenko, "Investigation of the composition of biologically active substances in extracts of wild plants", Voprosy Pitaniia, vol. 85, iss. 5, pp. 100-107, 2016.

[15] I.I. Novikova, A.I. Litvinenko, I.V. Boikova, V.A. Yaroshenko, and G.V. Kalko, "Biological activity of new microbiological preparations alirins B and $\mathrm{S}$ designed for plant protection against diseases. I. Biological activity of alirins against diseases of vegetable crops and potato", Mikologiya I Fitopatologiya, vol. 37, iss.1, pp. 92-98, January 2003.

[16] R. Trabelsi, H.Sellami, Y. Gharbi, S. Krid, M. Cheffi, S. Kammoun, M. Dammak, A. Mseddi, R. Gdoura, and M.A. Triki, "Morphological and molecular characterization of Fusarium spp. associated with olive trees dieback in Tunisia", 3 Biotech, vol. 7, p. 28, April 2017.

[17] I.D. Borca, E.P. Carmen, "Studies regarding the morphological identification of Fusarium sambucinum fuckel isolated from potato tubers", ProEnvironment, vol. 6, pp.59-63, March 2013. 